\title{
PERANCANGAN SISTEM IRIGASI OTOMATIS DENGAN WIRELESS SENSOR NETWORK (WSN) BERBASIS ENERGI SURYA
}

\author{
Dwi Waluyo Putranto \\ Fakultas Teknik, Jurusan Teknik Elektro \\ Universitas Widyagama Malang \\ Email: dwi_smilec@ymail.com \\ Feni Budi Antono \\ Fakultas Teknik, Jurusan Teknik Elektro \\ Universitas Widyagama Malang \\ Rizki Handoko \\ Fakultas Teknik, Jurusan Teknik Elektro \\ Universitas Widyagama Malang \\ Istiadi \\ Fakultas Teknik, Jurusan Teknik Elektro \\ Universitas Widyagama Malang \\ Email: istiadi@widyagama.ac.id
}

\begin{abstract}
ABSTRAK
Para petani di Indonesia umumnya masih menggunakan sistem pengairan yang tradisional yaitu dengan cara mengamati kondisi lahan untuk mengatur pengairannya. Selain itu pengairan tradisional kurang memperhatikan efisiensi penggunaan air, disisi lain jumlah petani cenderung berkurang karena generasi muda kurang berminat menjadi petani. Karena itu dibutuhkan sistem irigasi yang otomatis untuk mengurangi kerja petani dan mengefisienkan penggunaan air serta ramah lingkungan. Penelitian ini bertujuan merancang sistem irigasi otomatis menggunakan Wireless Sensor Network (WSN) berbasis tenaga surya. Pada sistem ini digunakan sensor kelembaban tanah untuk mendeteksi kondisi lahan. Hasil deteksi dikirimkan ke server dan untuk menentukan pengaktifan valve saluran air. Pengembangan sistem ini didasarkan obyek lahan di Kelompok Gapoktan sebagai contoh kasus. Hasil pengembangan sistem menunjukkan pengairan dapat bekerja mengalirkan air pada area tertentu sesuai dengan deteksi kondisi kelembaban tanahnya.
\end{abstract}

Kata kunci: sistem kontrol; pertanian; kelembaban tanah.

\begin{abstract}
The farmers in Indonesia generally still use the traditional irrigation system that is by observing the condition of the land to regulate the irrigation. In addition, the traditional irrigation is less attention to the efficiency of water use, on the other hand the number of farmers tend to decrease because the younger generation less interested in becoming farmers. Therefore, an automatic irrigation system is needed to reduce the farmers' work and to make efficient use of water and environmentally friendly. This study aims to design an automatic irrigation system using a solar-based Wireless Sensor Network (WSN). In this system used the soil moisture sensor to detect the condition of the land. The detection results are sent to the server and to determine the activation of the water channel valve. The development of this system is based on the object of land in Gapoktan Group as a case example. The result of the system development shows irrigation can work to drain water in certain area according to detection of soil moisture condition.
\end{abstract}

Keywords: control system; agriculture; soil moisture.

\section{PENDAHULUAN}

Indonesia merupakan negara agraris yang hampir seluruh wilayahnya terdapat sektor pertanian atau perkebunan sebagai sumber utama mata pencarian. Air merupakan hal yang penting dalam pememenuhan kebutuhan tanaman. Pengaturan aliran air atau irigasi di lahan pertanian merupakan faktor penting yang mempengaruhi hasil produksi pertanian atau perkebunan. Irigasi pada umumnya mengambil sumber air 
langsung dari sungai ke lahan sehingga air akan meresap sendiri ke pori-pori tanah. Irigasi secara konvensional ini belum mampu mengelola air dengan tepat dan efisien karena jumlah air yang diperlukan sangat banyak serta tidak berdasarkan kebutuhan.

Desa Torongrejo berada di ketinggian 700 dpl dengan luas $400 \mathrm{Ha}$, sawah $203 \mathrm{Ha}$, tegalan $45 \mathrm{Ha}$, pemukiman 151 terdiri dari 3 padusunan, yaitu Dusun Klerek, Dusun Tutup, Dusun Ngukir. Desa Torongrejo yang berada di Kecamatan Junrejo Kota Batu merupakan sentra usaha agroindustri, diantaranya terdapat usaha pembiayaan budidaya pertanian, persewaan mesin-mesin pertanian, jasa pengujian sawah, sayur-sayuran, peternakan dan penjualan pupuk serta obat-obatan pertanian. Di Desa Torongrejo terdapat gabungan kelompok tani (Gapoktan) Torong Makmur yang khusus untuk produk sayur mayur.

Beberapa kendala yang dihadapi para petani Gapoktan Torong Makmur yang pertama adalah sumber daya manusia (SDM). Di karenakan generasi muda lebih tertarik pada sektor pariwisata. Permasalahan kedua adalah terbatasnya pasokan air irigasi di saat kemarau. Pada daerah lahan kering, sebagian besar irigasi hanya mengandalkan air hujan saja. Salah satu upaya yang dapat dilakukan adalah penghematan air pada teknologi irigasi. Salah satu teknologi hemat air adalah sistem irigasi curah atau sprinkler. Teknologi irigasi curah merupakan salah satu irigasi yang cocok digunakan di lahan kering baik di tanah datar dan bergelombang [1]. Permasalahan ketiga adalah irigasi atau pengairan yang dilakukan masih tradisional. Petani umumnya mengunjungi lahannya secara periodik untuk melihat kondisi kelembaban tanah pada tanaman dan mengairinya hanya dengan perkiraan saja. Selain itu pada kondisi tertentu petani melakukan irigasi menggunakan mesin diesel. Hal ini menyebabkan polusi dan membutuhkan biaya untuk bahan bakar. Berdasarkan uraian permasalahan di atas, maka diperlukan suatu alternatif irigasi yang lebih efisien dalam penggunaan air dan dapat mengurangi kerja petani serta ramah lingkungan. Suatu sistem yang otomatis dalam pengairan diharapkan dapat menjadi solusi permasalahan tersebut. Sistem tersebut diharapkan mampu mendeteksi kondisi tanah dan menginformasikannya pada sistem kendali untuk mengairi area yang membutuhkan penyiraman saja. Hal ini memungkinkan untuk dikembangkan dengan teknologi WSN yang mampu mengirimkan data hasil penyensoran secara jarak jauh. Sensor Soil Moisture YL-69 dapat dimanfaatkan untuk mendeteksi kondisi kelembaban tanah [2]. Serta mikrokontroler arduino nano yang digunakan sebagai pengendali elektronik. Arduino Nano adalah papan mikrokontroler berbasis ATmega328. Arduino nano memiliki 14 pin digital input atau output (6 pin dapat digunakan sebagai output PWM), 8 input analog [3]. Untuk output, digunakan solenoid valve sebagai pengendali penyaluran air irigasi melalui relay yang diaktivasi oleh mikrokontroler [1].

Pemberian air irigasi di lahan pertanian maupun perkebunan bertujuan agar pemenuhan kebutuhan air pada masa pertumbuhan tanaman dalam berjalan dengan maksimal. Kenyataan di lapangan, air irigasi diberikan secara tidak terkendali sehingga terjadi ketidaksesuaian suplai air pada kebutuhan tanaman dan berakibat pemborosan pada air [4]. Sistem kontrol irigasi otomatis merupakan solusi dalam mengatasi permasalahan tersebut. Sistem kontrol irigasi telah banyak diterapkan, diantaranya Wiranto dkk (2014) mengembangkan sistem kontrol irigasi otomatis nirkabel. Saptomo dkk (2016) mengembangkan irigasi curah otomatis berbasis sistem pengendali mikro. Syamsiar (2016) dalam rancang bangun sistem irigasi tanaman otomatis menggunakan wireless sensor network.

Untuk komunikasi data, digunakan modul tranceiver nRF24L01+ yang dapat difungsikan sebagai transmitter maupun receiver. Tranceiver nRF24L01+ merupakan modul komunikasi yang memanfaatkan gelombang RF $2.4 \mathrm{GHz}$ untuk mengirimkan atau menerima data melalui gelombang radio [5]. Pengendali elektronik yang diterapkan memiliki kemampuan dalam memonitoring sistem irigasi pada lokasi yang berjauhan serta memberi keputusan dalam seberapa banyak air yang dibutuhkan untuk menyiram tanaman, sesuai dengan data yang diterima dari transmitter [6].

Tiap tahun kebutuhan energi listrik dunia akan terus mengalami kenaikan. Hal ini juga berlaku di Indonesia. Selama kurun waktu 17 tahun (2003 sampai dengan 2020) total kebutuhan listrik di Indonesia diperkirakan tumbuh sebesar 6,5\% per tahun dari 91,72 TWh pada tahun 2002 menjadi 272,34 TWh pada tahun 2020 (Muchlis \& Permana, 2003) [7]. Berdasarkan hal tersebut, beberapa tahun terakhir ini banyak pihak yang telah memanfaatkan energi terbarukan berbasis energi surya guna mencegah terjadinya lonjakan energi listrik. Penggunaan energi surya sangat potensial, karena total intensitas cahaya matahari di Indonesia mampu mencapai $4500 \mathrm{Wh} / \mathrm{m} 2$ perhari sehingga Indonesia termasuk negara yang kaya akan energi matahari (Yuliarto, 2008). Energi surya yang akan diterapkan terdiri dari panel surya sebagai sumber listrik yang menyimpan energi ke accu dengan pengontrol arus menggunakan solar charge controller (SCC) [8]. Kemudian energi listrik dari accu digunakan untuk menggerakan pompa air DC untuk mengisi air pada tandon. Dengan demikian kegiatan ini dimaksudkan untuk mengembangkan model sistem irigasi otomatis menggunakan WSN dengan memanfaatkan tenaga surya sebagai sumber energi yang ramah lingkungan. 


\section{METODOLOGI PENELITIAN}

\subsection{Lokasi Penelitian}

Lokasi penelitian ini dilakukan di lahan milik Gapoktan (Gabungan Kelompok Tani) Torong Makmur Kecamatan Junrejo Kota Batu.

\subsection{Tahap Pelaksanaan}

a. Observasi lapang dan studi literatur

Observasi ini dimaksudkan untuk mengetahui kondisi obyek penelitian. Studi literature untuk mendapatkan referensi terkait dengan pengembangan sistem seperti konsep WSN, sensor kelembaban tanah, dan sistem panel surya.

b. Perancangan Alat

Berdasarkan hasil observasi dan studi literatur dilakukan perancangan alat yang meliputi rancangan sistem penyiraman, rangkaian elektronik, dan rancangan algoritma program.

c. Pembuatan Alat

Pada tahap ini pembuatan alat dilakukan melalui tahapan pengadaan komponen, perakitan alat dan pembuat pemrograman alat sesuai dengan rancangan yang telah dibuat. Alat akan ditempatkan pada suatu chasing yang ditata sedemikian rupa agar portabel.

d. Pengujian dan Evaluasi

Pada tahap awal pengujian dilakukan untuk memastikan berfungsinya bagian-bagian alat. Evaluasi dilakukan untuk perbaikan dan penyempurnaan alat agar tujuan dari program yang diharapkan dapat tercapai dengan baik.

e. Penerapan Alat

Setelah alat dipastikan dapat bekerja dengan baik, selanjutnya dilakukan penerapan pada lahan mitra. Penerapan alat ini untuk mengetahui kinerjanya ketika diterapkan pada lokasi yang telah ditentukan.

\section{HASIL DAN PEMBAHASAN}

Berdasarkan observasi pada salah satu petak lahan anggota kelompok mitra yang dijadikan obyek dengan ukuran $2 \times 4$ meter. Lahan itu sedang ditanami bawang yang terdiri atas tiga galur. Dengan kondisi tersebut maka rancangan sistemnya terbagi atas tiga saluran cabang (lateral) dengan tiga titik sampel sensor yang ditempatkan pada masing-masing jalur (Gambar 1).

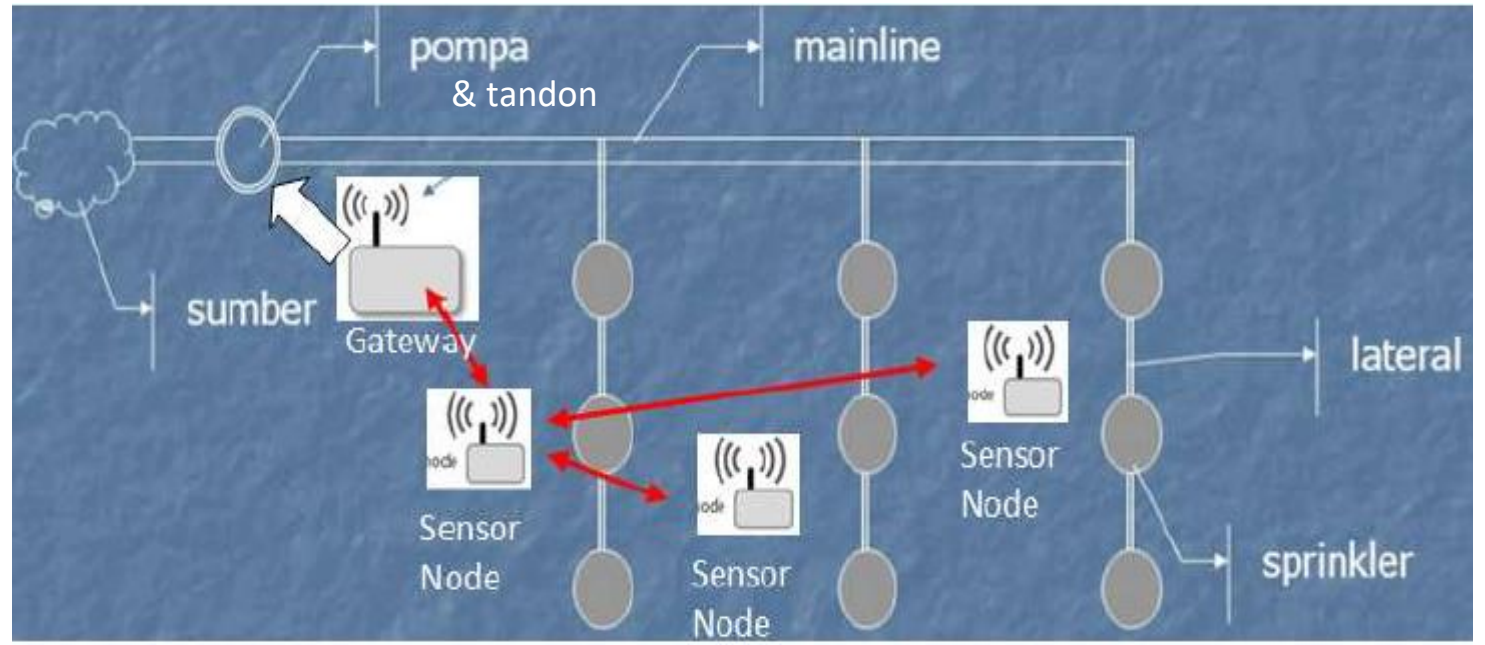

Gambar 1. Rancangan Sistem Kontrol Irigasi pada petak lahan Mitra

Berdasarkan rancangan tersebut selanjutnya diimplementasikan sistem kendalinya dalam bentuk rangkaian elektronik (hardware) dan program kendalinya (software). Rangkaian elektronik terdiri dari rangkaian node sensor (Gambar 2a), rangkaian server gateway (Gambar 2b) dan sistem energi surya (Gambar 2c). 


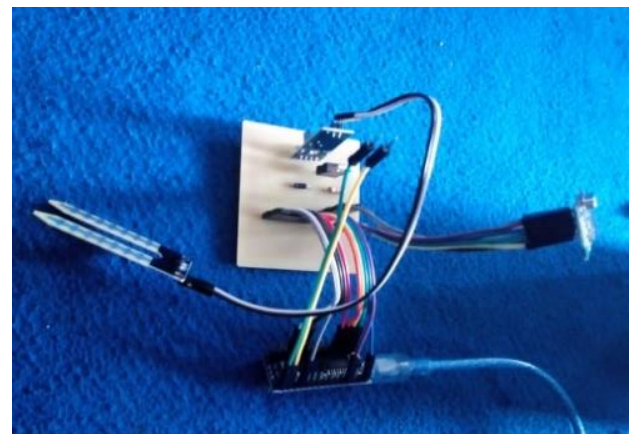

( a )

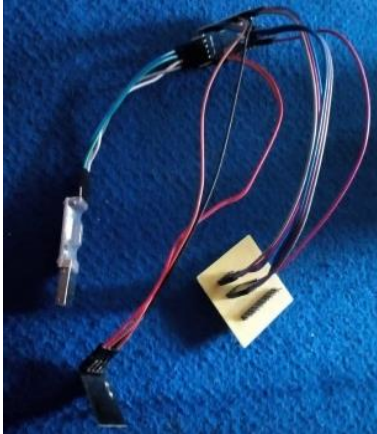

( b )

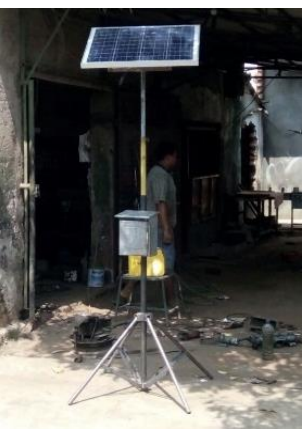

(c)

\section{Gambar 2. Bagian Sistem Elektronik (a) Node Sensor (b) Server (c) Sistem Panel Surya}

Rangkaian Node Sensor berupa sensor kelembaban tanah (YL-69), arduino nano, solenoid valve, driver dan modul nRF24L01+. Rangkaian Server berupa arduino nano dan modul nRF24L01+. Sistem energi surya terdiri dari panel surya, accu, SCC dan pompa DC. Setelah keseluruhan hardware dibuat, selanjutnya akan dirancang sistem kontrol pada alat. Sistem kontrol diterapkan pada server yang akan membaca data kelembaban tanah dari node sensor dan menentukan untuk buka atau tutup aliran irigasi sesuai setpoint. Diagram alir sistem kontrol ditampilkan pada Gambar 2.

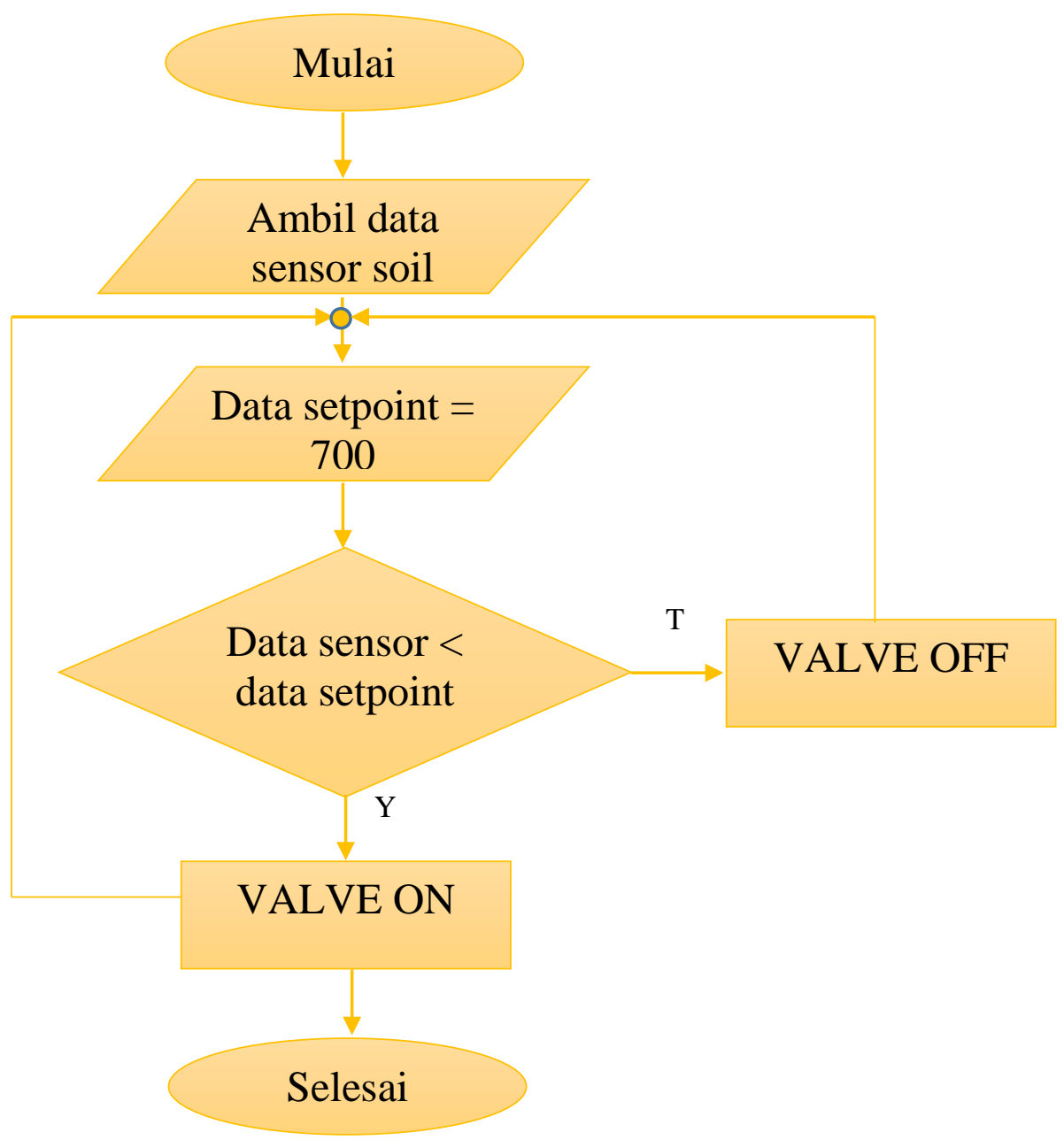

Gambar 3. Diagram Alir Sistem Kontrol Irigasi

Berdasarkan pada gambar 3, dapat diketahui mekanisme pengendalian sistem irigasi. Suatu data setpoint ditentukan sebagai acuan kelembaban tanah yang diharapkan. Data setpoint tersebut digunakan sebagai pembanding terhadap hasil pembacaan data dari sensor kelembaban. Jika data sensor kelembaban 
tanah lebih rendah dari data setpoint maka Valve akan diaktifkan (ON), tetapi jika data sensor kelembaban tanah lebih tinggi dari data setpoint maka Valve akan dinonaktifkan (OFF).

Selanjutnya dilakukan pengujian pada bagian-bagian sistem tersebut. Pengujian pertama adalah komunikasi antara Node Sensor terhadap Server. Pengujian ini dimaksudkan untuk mengetahui jarak bekerjanya sistem komunikasi antara node sensor dengan Server (Gateway) yang bisa dijangkau. Pengujian dilakukan dengan mengirimkan sampel data kelembaban dan status valve dari suatu node sensor kepada server pada jarak-jarak tertentu sehingga diketahui jarak yang masih cukup baik diterimanya data. Dalam hal ini diuji coba dengan maksimum jaraknya adalah 50 meter karena pada mitra ukuran panjang lahan maksimum adalah sekitar 50 meter.

Tabel 1. Pengujian jarak komunikasi node sensor ke server

\begin{tabular}{cccc}
\hline $\begin{array}{c}\text { Jarak } \\
\text { Meter })\end{array}$ & $\begin{array}{c}\text { Data Dikirim (Kelembaban Tanah, Status Valve) } \\
\text { Node Sensor }\end{array}$ & $\begin{array}{c}\text { Data Diterima } \\
\text { Server }\end{array}$ & Keterangan \\
\hline 10 & $236, \mathrm{ON}$ & $236, \mathrm{ON}$ & Komunikasi Baik \\
20 & $245, \mathrm{ON}$ & $245, \mathrm{ON}$ & Komunikasi Baik \\
30 & $264, \mathrm{ON}$ & $264, \mathrm{ON}$ & Komunikasi Baik \\
40 & $302, \mathrm{ON}$ & $302, \mathrm{ON}$ & Komunikasi Baik \\
50 & $417, \mathrm{ON}$ & $417, \mathrm{ON}$ & Komunikasi Baik \\
\hline
\end{tabular}

Berdasarkan data pengujian komunikasi antara Node Sensor ke Server dengan mengirimkan data kelembaban dan status Valve dapat diketahui bahwa komunikasi berjalan dengan baik. Dapat dilihat pada Tabel 1 memiliki hasil yang sama antara data pada node sensor dengan data pada Server untuk setiap titik jarak uji mulai jarak terpendek (10 meter) sampai dengan jarak terjauh (50 meter).

Pengujian kedua adalah pengujian panel surya. Panel surya yang digunakan berkapasitas 50 WP (wattpeak) yang berarti memiliki daya produksi maksimal pada waktu tertentu atau biasa disebut jam efektif sekitar 3-5 jam perhari. Pengujian panel surya dilakukan dengan melakukan pengukuran tegangan keluaran pada jam-jam tertentu. Dalam hal ini dilakukan mulai jam 9.00 sampai dengan jam 15.00 dengan interval pengukuran adalah 30 menit. Hasil pengujian panel surya disajikan pada Tabel 2.

Tabel 2. Pengukuran Tegangan Panel Surya

\begin{tabular}{cc}
\hline Waktu $($ WIB $)$ & Tegangan Panel Surya $($ Volt $)$ \\
\hline $9: 00$ & 18.5 \\
$10: 00$ & 18.1 \\
$11: 00$ & 18.4 \\
$12: 00$ & 18.1 \\
$13: 00$ & 15.9 \\
$14: 00$ & 18.1 \\
$15: 00$ & 16.2 \\
\hline
\end{tabular}

Dari data hasil pengukuran tegangan panel surya pada Tabel 2 di atas menunjukkan bahwa tegangan yang dihasilkan panel surya setiap waktu yang berbeda tergantung panas yang diserap oleh panel surya tersebut dan juga radiasi cahaya panas matahari yang menyinari panel tersebut. Berdasarkan pada Tabel 2, maka dapat diketahui tegangan yang dihasilkan oleh panel surya tidak stabil, hal ini karena faktor cuaca yang tidak menentu dan intensitas cahaya matahari yang diterima selalu berubah-ubah. Pada saat cuaca mendung, tegangan panel surya tertinggi terjadi pada jam 9.00 yaitu sebesar 18.5 Volt dan tegangan terendah terjadi pada jam 13.00 yaitu sebesar 15.9 Volt. Rata-rata tegangan yang dihasilkan dari seluruh pengujian sekitar 17.6 Volt.

Selanjutnya pengujian pengisian tandon dengan kapasitas 100 liter yang di suplai dari accu yang bersumber dari panel surya. Ketinggian tandon adalah 3,7 meter. Pada penelitian ini yang digunakan adalah accu Yuasa 12V 17.2Ah. Pengukuran penggunaan accu yang dilakukan bertujuan untuk mengetahui lamanya waktu pengisian tandon dan kemampuan accu melalui pengukuran tegangan dan arus listriknya. Beban accu berupa pompa DC 60 Watt. Hasil pengujian ditampilkan pada Tabel 3. 
Tabel 3. Pengukuran penggunaan accu

\begin{tabular}{cccc}
\hline \multirow{2}{*}{ Waktu (Menit) } & $\begin{array}{c}\text { Ketinggian } \\
\text { Tandon (Meter) }\end{array}$ & $\begin{array}{c}\text { Tegangan } \\
\text { Accu (Volt) }\end{array}$ & $\begin{array}{c}\text { Arus Penggunaan Pompa } \\
\text { DC (Ampere) }\end{array}$ \\
\hline \multirow{2}{*}{ 12:20 - 12:31 } & & 11.4 & 4.5 \\
$(11$ menit) & 3.7 & 11.3 & 4.2 \\
& & 11.2 & 4.3 \\
$13: 00-13: 13$ & 3.7 & 11.2 & 4.2 \\
$(13$ menit) & & 11.1 & 4 \\
& & 11 & 3.9 \\
$13: 30-12: 42$ & 3.7 & 10.9 & 3.9 \\
$(12$ menit) & & 10.7 & 3.8 \\
$13: 50-14: 05$ & 3.7 & 10.7 & 3.8 \\
$(15$ menit) & & 10.7 & 3.6 \\
& & 10.6 & 3.6 \\
\hline
\end{tabular}

Berdasarkan Tabel 3, maka dapat diketahui lama waktu penggunaan accu dengan beban pompa DC 60 Watt masih dapat bertahan untuk pengisian tandon mulai kosong hingga penuh setidaknya 4 kali. Pada kondisi tersebut tegangan kerja menurun menjadi $10.5 \mathrm{~V}$ dengan arus sebesar $3.5 \mathrm{~A}$. Hal ini menunjukkan kemampuan accu cukup baik karena kapasitas accu dapat bertahan yang memungkinkan diisi lagi dengan suplai panel surya.

Pengujian selanjutnya adalah terkait charging accu dengan panel surya. Pengukuran charging accu dilakukan tanpa menggunakan beban, hal ini bertujuan untuk mengetahui lamanya waktu charging panel surya dengan tegangan awal 12.6 Volt hingga 12.9 Volt. Hasil pengukuran pengisian accu ditampilkan pada Tabel 4.

Tabel 4. Pengukuran charging accu dengan panel surya

\begin{tabular}{cccc}
\hline Waktu (WIB) & $\begin{array}{c}\text { Tegangan } \\
\text { Panel Surya } \\
\text { (Volt) }\end{array}$ & $\begin{array}{c}\text { Arus } \\
\text { Charging } \\
\text { (Ampere) }\end{array}$ & $\begin{array}{c}\text { Tegangan Accu } \\
\text { (Volt) }\end{array}$ \\
\hline $10: 23$ & 16.8 & 1.66 & 11.3 \\
$10: 55$ & 16.6 & 1.36 & 11.6 \\
$11: 32$ & 19.4 & 1.66 & 11.7 \\
$12: 00$ & 15.7 & 1.50 & 11.9 \\
$12: 35$ & 16 & 1.25 & 12.2 \\
\hline
\end{tabular}

Dari hasil pengukuran di atas dapat disimpulkan proses pengisian accu dengan tegangan mulai 11,3 sampai 12,2 Volt membutuhkan waktu sekitar 2 jam. Dengan demikian pengisian accu untuk setiap Voltnya dibutuhkan waktu sekitar 2 jam. Pengukuran ini bertujuan untuk membuktikan bahwa alat dapat melakukan proses pengisian accu.

Tahap akhir adalah pengujian sistem kontrol irigasi. Dalam tahap pengujian sistem kontrol irigasi terdiri dari sensor soil moisture, arduino, solenoid valve, driver dan accu. Sensor soil moisture memiliki empat buah pin. Pin 1 untuk vcc, pin 2 untuk output sensor analog, pin 3 untuk output sensor digital dan pin 4 untuk ground. Nilai output sensor soil moisture yang digunakan adalah berupa data analog. Sensor soil moisture disuplai tegangan sebesar 5 volt, berarti memiliki rentang nilai digital 0 sampai 1023. Skala kelembaban tanah dalam pertanian biasanya ditunjukkan oleh sensor dengan nilai digital 0-300 untuk kering, 300-700 untuk lembab dan 700-1023 untuk basah. Sedangkan aktuator berupa solenoid valve akan terhubung dengan pin digital arduino sebagai output digital. Pada kondisi tanah kering, solenoid valve akan membuka aliran air dan jika tanah basah, solenoid valve akan menutup aliran air sehingga kelembaban tanah selalu berada pada nilai setpoint. Pada pengujian ini dibuat setpoint pada nilai kelembaban tanah 700. Dari hasil pengujian sistem kontrol irigasi didapatkan data yaitu: 
Tabel 5. Pengujian Sistem Kontrol Irigasi

\begin{tabular}{|c|c|c|c|}
\hline $\begin{array}{c}\text { Nilai } \\
\text { Kelembaban } \\
\text { Tanah (Awal) }\end{array}$ & $\begin{array}{c}\text { Status } \\
\text { Solenoid Valve } \\
(\text { ON/OFF })\end{array}$ & $\begin{array}{c}\text { Lama Penyiraman } \\
\text { (Menit, Detik) }\end{array}$ & $\begin{array}{c}\text { Nilai } \\
\text { Kelembaban } \\
\text { Tanah (Akhir) }\end{array}$ \\
\hline 103 & $\mathrm{ON}$ & \pm 3 menit 7 detik & 690 \\
\hline 245 & ON & \pm 2 menit 42 detik & 693 \\
\hline 330 & ON & \pm 2 menit 3 detik & 698 \\
\hline 427 & $\mathrm{ON}$ & \pm 1 menit 35 detik & 694 \\
\hline 578 & $\mathrm{ON}$ & \pm 1 menit 2 detik & 699 \\
\hline 630 & ON & \pm 1 menit 0 detik & 693 \\
\hline$>700$ dan $<1023$ & OFF & - & $700-1023$ \\
\hline
\end{tabular}

Dari data hasil pengujian sistem kontrol irigasi pada Tabel 5 menunjukkan bahwa nilai sensor yang berada diantara 103-330 menunjukan bahwa tanah dalam keadaan kering sehingga dibutuhkan lebih banyak waktu untuk penyiraman. Nilai sensor yang berada diantara 300-690 menunjukan bahwa tanah dalam keadaan lembab, sedangkan nilai sensor yang berada diantara 700-1023 menunjukkan bahwa tanah tersebut dalam keadaan basah sehingga solenoid valve tetap menutup katup.

\section{KESIMPULAN}

Berdasarkan hasil pengembangan sistem irigasi dan hasil pengujiannya menunjukkan bahwa sistem irigasi menggunakan WSN dapat mengendalikan penyaluran pengairan berdasarkan area titik sensor kelembaban tanah. Ukuran setpoint kelembaban tanah dapat ditentukan, sehingga pengendalian pengairan dapat disesuaikan dengan kebutuhan tanaman dan kondisi tanah. Sistem panel surya yang digunakan untuk mensuplai air ke tandon perlu disesuaikan dengan kebutuhan area penyiraman dan pompa dc yang digunakan.

\section{UCAPAN TERIMA KASIH}

Tim penulis menyampaikan terima kasih kepada Direktorat Jenderal Pembelajaran dan Mahasiswa Kementerian Riset Teknologi dan Pendidikan Tinggi (Ditbelmawa KEMENRISTEKDIKTI) yang telah mendanai kegiatan ini melalui Program Kreativitas Mahasiswa bidang Penerapan Teknologi (PKM-T).

\section{DAFTAR PUSTAKA}

[1] S. K. Saptomo, R. Isnain, and B. I. Setiawan, "Irigasi curah otomatis berbasis sistem pengendali mikro,” Jurnal Irigasi, vol. 8, no. 2, pp. 115-125, 2016.

[2] M. D. Syamsiar, M. Rivai, and S. Suwito, "Rancang Bangun Sistem Irigasi Tanaman Otomatis Menggunakan Wireless Sensor Network," Jurnal Teknik ITS, vol. 5, no. 2, pp. A261-A266, 2016.

[3] Anonim. Arduino Nano. [Online] Available at : https://store.arduino.cc/usa/arduino-nano, diakses tanggal 20 Agustus 2018.

[4] B. I. Setiawan and S. K. Saptomo, "Sistem Kontrol Irigasi Otomatis Nirkabel," Jurnal Irigasi, vol. 9, no. 2, pp. 108-114, 2014.

[5] D. I. Af'idah, A. F. Rochim, and E. D. Widianto, "Perancangan Jaringan Sensor Nirkabel (JSN) untuk Memantau Suhu dan Kelembaban Menggunakan nRF24L01+," Jurnal Teknologi dan Sistem Komputer, vol. 2, no. 4, pp. 267-276, 2014.

[6] C. Rozikin, H. Sukoco, and S. K. Saptomo, "Sistem Akuisisi Data Multi Node untuk Irigasi Otomatis Berbasis Wireless Sensor Network," Jurnal Nasional Teknik Elektro dan Teknologi Informasi (JNTETI), vol. 6, no. 1, 2017.

[7] M. F. Hakim, "Perancangan Rooftop Off Grid Solar Panel Pada Rumah Tinggal Sebagai Alternatif Sumber Energi Listrik,” DINAMIKA DOTCOM, vol. 8, no. 1, 2017.

[8] S. H. Subandi, "Pembangkit Listrik energi matahari sebagai penggerak pompa air dengan 
Jurnal SIMETRIS, Vol. 9 No. 2 November 2018

P-ISSN: 2252-4983, E-ISSN: 2549-3108

menggunakan solar cell," Jurnal Teknologi Technoscientia ISSN, vol. 8415, pp. 157-163, 1979. 